\title{
Beç tavuğu etinin kimyasal ve yağ asidi kompozisyonu üzerine yetiştirme sistemi ve kesim yaşının etkisi
}

\section{Effect of production system (intensive and free-range), and slaughter age on chemical and fatty acid composition of meat in guinea fowl}

\author{
Mehmet Akif BOZ ${ }^{1^{*}}$, Fatih ÖZ ${ }^{2}$, Musa SARICA ${ }^{3}$ iD, Umut Sami YAMAK ${ }^{4}$ iD \\ ${ }^{1}$ Yozgat Bozok University, Faculty of Agriculture, Department of Animal Science, Yozgat/Turkey \\ ${ }^{2}$ Atatürk University, Faculty of Agriculture, Department of Food Engineering, Erzurum/Turkey \\ ${ }^{3,4}$ Ondokuz Mayıs University, Faculty of Agriculture, Department of Animal Science, Samsun/Turkey \\ ${ }^{1}$ https://orcid.org/0000-0002-7452-6895; ${ }^{2}$ https://orcid.org/0000-0002-5300-7519; ${ }^{3 h t t p s: / / o r c i d . o r g / 0000-0001-5331-0596 ; ~}$ \\ ${ }^{4}$ https://orcid.org/0000-0002-6435-4866
}

\section{To cite this article:}

Boz, M., Öz, F., Sarıca, M. \& Yamak, U.S. (2021). Beç tavuğu etinin kimyasal ve yağ asidi kompozisyonu üzerine yetiştirme sistemi ve kesim yaşının etkisi. Harran Tarım ve Gıda Bilimleri Dergisi, 25(3):349-361.

DOI:10.29050/harranziraat.886982

*Address for Correspondence: Mehmet Akif BOZ

e-mail:

bozmakif@gmail.com

Received Date:

25.02.2021

Accepted Date:

22.05.2021

(c) Copyright 2018 by Harran University Faculty of Agriculture. Available on-line at www.dergipark.gov.tr/harranziraat

\section{öz}

$\mathrm{Bu}$ çalışma, beç tavuklarında yetiştirme sistemi ve kesim yaşının etin kimyasal kompozisyonu, yağ asitleri profili ve yağ asitlerinden oluşturulan indeks değerler üzerine etkisini belirlemek amacıyla yürütülmüştür. Çalışmanın materyalini serbest gezinmeli ve kapalı sistemde 14, 16 ve 18 hafta yetiştirilmiş (erkek ve dişi karışık) beç tavuklarından elde edilen derisiz göğüs ve but eti örnekleri oluşturmaktadır. Yetiştirme sistemi ve kesim yaşının göğüs eti kimyasal kompozisyonu üzerine etkisi önemsiz olmuştur. But etinde ise kuru madde oranı yaşa bağlı farklılık göstermiştir. Kapalı sistemde yetiştirilen beç tavuklarının göğüs etinde C18:1n9c, T+ÇDYA, n-9, TDYA/DYA, ÇDYA/DYA, BDi, $h / \mathrm{H}$ ve iYA daha yüksek oranda bulunmuştur. Serbest gezinmeli sistemde yetiştirilen beç tavuklarının ise göğüs etinde C16:0, C18:0, C22:1n9, DYA, Al ve TI daha yüksek belirlenmiştir. But etinde C18:0 kapalı, C18:1n9c, TDYA, n-9 ve TDYA/DYA ise serbest gezinmeli yetiştirme sisteminde daha yüksek belirlenmiştir. Yaşa bağlı olarak but eti C20:1 oranında azalma, C22:1n9 ve n-3 oranında ise artış meydana gelmiştir. Göğüs etinde ise yaş ile birlikte C22:1n9, n-9 ve TDYA/DYA oranında artış belirlenmiştir. Sonuç olarak her iki yetiştirme sistemi arasında bazı değerler açısından farklılıklar oluşmuştur. Bununla birlikte genel değerlendirmede kapalı ve serbest gezinmeli yetiştirme sisteminin üretim için uygun olduğu görülmektedir. Tüketiciler açısından ise doymuş yağ asitleri ve buna bağlı değerlerin dikkate alınması gerektiği düşünülmektedir.

Anahtar Kelimeler: Beç tavuğu, Yetiştirme sistemi, Kesim yaşı, Yağ asitleri

\section{ABSTRACT}

This study was carried out to determine the effects of the production system and slaughter age on chemical composition, fatty acid profile and index values formed from fatty acids in guinea fowls. The material of the study consists of skinless breast and thigh meat samples obtained from guinea fowl chickens (male and female mixed) reared for 14,16 , and 18 weeks in the free range and intensive systems. The effect of the production system and slaughter age on breast meat chemical composition was insignificant. Dry matter rate in thigh meat showed a difference depending on age. C18:1n9c, TUFA, $n-9$, MUFA/UFA, PUFA/SFA, NVI, h/H, and DFA were higher in breast meat of guinea fowls reared in the intensive system. C16:0, C18:0, C22: 1n9, SFA, Al, and TI were found higher in the breast meat of guinea fowls reared in the free-range system. In thigh meat, C18:0 was higher in the intensive system, while C18:1n9c, MUFA, $n-9$, and MUFA / SFA were higher in the free-range system. Depending on the age, there was a decrease in the proportion of C20:1 in thigh meat and an increase in C22:1n9 and n-3. In the breast meat, an increase in the proportion of C22:1n9, n-9, and MUFA/SFA was determined with age. As a result, although there are some differences between intensive and free-range systems in terms of some traits, both systems are considered to be suitable for production. Saturated fatty acids values should be taken into consideration for consumer health.

Key Words: Guinea fowl, Production systems, Slaughter age, Fatty acids 


\section{Giriş}

Tavuğa alternatif et olarak beç tavuğu etinin Amerika Birleşik Devletleri, Kanada, Fransa ve İtalya gibi Avrupa pazarlarında karlı bir faaliyet olduğu kanıtlanmış, dünyanın çeşitli yerlerinde potansiyel olarak karlı bir girişim olarak kabul edilmiştir (Embury, 2001; Nahashon ve ark., 2005; Tufarelli ve ark., 2007; Laudadio ve ark., 2012). Bu nedenle beç tavuklarının üretiminde bir artış gözlenmektedir. Dünyada artan nüfus ile birlikte protein ihtiyacının da artması, hayvansal kökenli protein kaynaklarının çeşitlendirilmesine neden olmuştur. Bunun sonucunda üreticiler protein ihtiyacının karşılanması bakımından alternatif kanatlı türlerine yönelmiştir. Ülkemizde de beyaz et ve yumurta üretimi amacıyla değerlendirilebilecek alternatif kanatlı türlerinden biri beç tavuklarıdır (Yıldırım, 2009). Ticari üretimde beç tavuğu, tavuklara benzer yönetim uygulamaları ile yetiştirilebilirler (Nahashon ve ark., 2009). Numidia familyanın üyesi olan beç tavukları olumsuz koşullara adaptasyon sağlayabilmekte, zor çevre koşullarında verim ve üreme sağlamakta, hastalıklara karşı yüksek dayanma gücü ortaya koymaktadır. Ayrıca ülkesel olarak hem ıslah materyali hem de gen kaynağı olarak da değerlendirilebilirler (Yıldırım, 2009). Ülkemizde Tarım ve Orman Bakanlığı, Doğa Koruma ve Milli Parklar Genel Müdürlüğü tarafından üretim istasyonlarında beç tavuğu yetiştirilmekte ve orman köylerine dağıtımı yapılmaktadır. Ülkemizde son yıllarda beç tavuğu eti üretiminde de önemli gelişmeler olmuştur. 2019 yılında 4.017 ton beç tavuğu eti ihracata konu olmuştur (Anonymous, 2021).

Son yıllarda tüketiciler kanatlı etlerinin üretim sistemi ile kalite özelliklerine daha fazla ilgi duymaktadır (Okruszek, 2012). Kanatlı etleri besleyici özelliklerinin yanı sıra, diğer protein kaynaklarından elde edilemeyen birçok besin öğesine de sahiptir. Etin besleyici değeri besin madde kompozisyonu ve yağ içeriği gibi parametrelere bağlıdır (Magdealine ve ark., 2008; Okruszek ve ark., 2013). Bununla birlikte, kanatlılarda et kalitesi hayvana bağlı ve hayvana bağıı olmayan birçok faktör tarafından etkilenebilmektedir. Bugüne kadar yapılan araştırmalar canlı ağırlık, karkas bileşimi ve et kalitesinin esas olarak genotip, yetiştirme sistemi ve yaştan etkilendiğini göstermektedir. Buna ek olarak, yetiştirme koşulları, besleme, yerleşim sıklığı, çevre şartları, cinsiyet, kesim öncesi kısa ve uzun süreli çevre koşulları ve interaksiyonları da önemli faktörlerdir (Castellini ve ark., 2002; Wood ve ark., 2008; Kokoszynski ve ark. 2011; Yakar ve Tekeli, 2019).

Beç tavuklarının kemik yapıları oldukça küçük, karkastaki et oranı ise kısmen daha yüksektir. Genç beç tavuklarının etleri lezzetli, sulu, gevrek, yağsız ve av hayvanları özelliğindedir. Yaşlı hayvanlarda ise etlerde sertleşme ve kuru madde artışı gerçekleşmektedir. Karkasları daha koyu görünüşe sahiptir (Sarıca ve ark., 2003). Bu çalışmada kullanılan beç tavuklarının 18 haftalık yaştaki canlı ağırlığı kapalı ve serbest gezinmeli sistemde (erkek dişi karışı) 1136-1246 gram arasında belirlenmiştir. Aynı dönemlerde yemden yararlanma oranları 5.80-6.43 olarak bulunmuştur (Sarıca ve ark., 2018). Musundire ve ark. (2017) 48 haftalık yaştaki beç tavuklarında canlı ağırlığı 920 - 974 gram arasında tespit etmiştir. Genotip, yaş ve mevsime bağlı olarak yürütülen bir çalışmada 96 günlük yaştaki beç tavuğu ağırlıkları 2100-2300 gram arasında bulunmuştur (Baeza ve ark., 2001). Beç tavuğu etinin yüksek proteine ve broylerlere kıyasla düşük yağ oranına sahip olduğu; dolayısıyla sağlıkla ilgili risklerinin daha az olabileceği bildirilmektedir (Madzimure ve Saina, 2011).

Broyler etinin insan sağlığını geliştirici özellikler sağlayan besinler ile zenginleştirilmesi kapsamlı bir şekilde araştırılmış olsa da, beç tavuğu gibi alternatif kümes hayvanlarına ilişkin bilgiler yetersizdir. Ülkemiz şartlarında beç tavuklarının birçok özelliği üzerine çalışma yapılması, yetiştiricilikte üretim etkinliğini arttıracaktır. Ayrıca çeşitli faktörlere bağlı olarak et kalite özelliklerinin belirlenmesi önemli bir alt yapı sağlayacaktır. Bu çalışma beç tavuklarının derisiz göğüs ve but eti örneklerinde besin madde ve yağ asitleri 
kompozisyonu üzerine yetiştirme sistemi ve kesim yaşının etkisini belirlemek amacıyla yürütülmüştür.

\section{Materyal ve Metot}

Denemede yürütülen tüm işlemler Ondokuz Mayıs Üniversitesi Deney Hayvanları Etik Kurulu tarafından onaylanmıştır (31.03.2015 - 2015/1624). Çalışmanın materyalini serbest gezinmeli ve kapalı sistemlerde 14, 16 ve 18 hafta yetiştirilmiş (erkek ve dişi karışık) beç tavuklarından elde edilen derisiz göğüs ve but eti örnekleri oluşturmaktadır. Beç tavuklarının yetiştirme, bakım ve besleme uygulamaları Yamak ve ark. (2018) ve Sarıca ve ark., (2019) tarafından açıklandığı şekilde yapılmıştır. Denemede kullanılan göğüs ve but eti örnekleri bu çalışmanın hayvan materyalinden temin edilmiştir.

Denemede günlük yaşta 200 adet beç tavuğu civcivi kullanılmıştır. Civcivler pencereli kümes içerisinde yetiştirme sistemlerine (kapalı ve serbest gezinmeli) rastgele seçilerek 4 tekerrürlü (her tekerrürde 25 adet) olarak yerleştirilmiştir. Bölmeler 3.5 x 3.5 m ölçülerindedir ve bölmelerin üst tarafı uçuş ile geçişi önlemek amacıyla 0.5 x 0.5 $\mathrm{cm}$ tel örgü ile kapatılmıştır. Her tekerrür bölmesinde 1 adet yemlik ve suluk bulundurulmuştur. Bölmelerde altlık olarak $8 \mathrm{~cm}$ derinlikte odun talaşı kullanılmıştır. Isıtma kızılötesi ısıtıcılar ile sağlanmıştır. Aydınlatma için ekonomik beyaz ampuller kullanılmıştır. İlk 3 gün 24 saatlik aydınlatma, daha sonra kademeli olarak (3-14. günler arasında) azaltılarak 6. haftaya kadar 20 saat aydınlatma uygulanmıştır. Bu haftadan kesime kadar ise doğal aydınlatma (yaklaşık 14 saat/gün) uygulanmıştır. Beç tavukları 6. haftadan itibaren serbest gezinmeli yetiştirme sisteminde 14 x 3.5 m ölçülerindeki gezinti alanına 50 × 90 cm'lik tek bir kapıdan 24 saat erişim sağlamıştır.

Tüm deneme gruplarında bulunan beç tavukları, 12 haftalık olana kadar başlangıç yemiyle ve 12 haftalıktan itibaren denemenin sonuna kadar büyütme yemi ile beslenmiştir. Yem bileşenleri Çizelge 1'de verilmiştir. Yem ve su ad libitum olarak sağlanmıştır.
Çizelge 1. Rasyon içeriği

Table 1. Nutrient contents of diets

\begin{tabular}{|l|c|c|}
\hline $\begin{array}{l}\text { İçerik } \\
\text { Ingredient }\end{array}$ & $\begin{array}{l}0-12 \text { hafta } \\
\text { O to } 12 \mathrm{wk}\end{array}$ & $\begin{array}{l}12-18 \text { hafta } \\
13 \text { to } 18 \mathrm{wk}\end{array}$ \\
\hline $\begin{array}{l}\text { Ham Protein (\%) } \\
\text { Crude Protein (\%) }\end{array}$ & 19 & 16 \\
\hline $\mathrm{ME} \mathrm{(MJ/kg)}$ & 11.72 & 11.30 \\
\hline $\begin{array}{l}\text { Lisin }(\mathrm{g} / \mathrm{kg}) \\
\text { Lysine }\end{array}$ & 10.00 & 7.20 \\
\hline $\begin{array}{l}\text { Metionin }(\mathrm{g} / \mathrm{kg}) \\
\text { Methionine }\end{array}$ & 4.00 & 3.50 \\
\hline $\begin{array}{l}\text { Kalsiyum }(\mathrm{g} / \mathrm{kg}) \\
\text { Calcium }\end{array}$ & 11.00 & 10.00 \\
\hline $\begin{array}{l}\text { Potasyum }(\mathrm{g} / \mathrm{kg}) \\
\text { Potassium }\end{array}$ & 7.00 & 4.00 \\
\hline
\end{tabular}

Kesim dönemlerinde rastgele seçilen beç tavuklarına, kesim öncesi 8 saat yem verilmemiş, bu süreçte suya ulaşım sağlanmıştır. Yarı otomatik sistemde kesilen beç tavuklarında ıslatma $\left(56^{\circ} \mathrm{C}\right.$ 'de 1 dakika), yolma, soğuk suyla soğutma, havalandırma, iç çıkarma ve soğutma işlemleri gerçekleştirilmiştir.

Göğüs ve but eti örneklerinden 4 tekerrürlü olmak üzere toplamda 48 örnek (2 yetiştirme sistemi $x \quad 3$ kesim yaşı) üzerinde analizler gerçekleştirilmiştir. Beç tavuklarının kesim sonrası göğüs ve but etine ait örnekleri $-18 /-22{ }^{\circ} \mathrm{C}^{\prime}$ de derin dondurucuda muhafaza edilmiştir. Beç tavuklarında ortalama kesim ağırlıkları, serbest gezinmeli sistemde 1144, kapalı sistemde 1153 gramdır. Yaşa bağlı kesim ağılıkları ise 14, 16 ve 18. haftada sırasıyla 1039, 1165 ve 1242 gram olarak belirlenmiştir (Yamak ve ark., 2018).

Örneklerin besin madde kompozisyonunun belirlenmesinde Gökalp ve ark. (2010)'ın yöntemi kullanılmıştır. Yağ asidi metil esterlerinin (FAME) oluşturulmasında AOAC 996.01 metodu kullanılmıştır (Satchithanandam ve ark., 2001). Eter ekstraksiyon yöntemi ile elde edilen $0.1 \mathrm{~g}$ yağ, $10 \mathrm{~mL}$ n-hekzan ile çalkalanmış, $0.5 \mathrm{~mL} 2 \mathrm{~N}$ metanollü potasyum hidroksit çözeltisi ilave edilerek tekrar karıştırılmıştır. 1-2 saat karanlık ortamda bekletildikten sonra üst fazdan $1 \mu \mathrm{L}$ gaz kromatografisine enjekte edilmiştir.Yağ asidi kompozisyonu; Shimadzu marka gaz kromatografi (model QP2010 Plus) cihazında alev iyonizasyon dedektör (FID) ve Restek RTX-2330 kapiler kolon (60 m, 0.25 mm i.d., $0.1 \mu \mathrm{m}$ film kalınlığı, Bellefonte, PA (USA) kullanılarak analiz edilmiştir. 
Kolon fırını sıcaklığı $100^{\circ} \mathrm{C}^{\prime}$ de $3 \mathrm{dk}$ tutulduktan sonra, dakikada $4^{\circ} \mathrm{C}$ artışla $240^{\circ} \mathrm{C}^{\prime}$ ye ulaştırılacak ve son sıcaklık derecesinde $18 \mathrm{dk}$. bekleyecek şekilde programlanmıştır. Enjeksiyon sıcaklığı $250^{\circ} \mathrm{C}$, dedektör sıcaklığı ise $255^{\circ} \mathrm{C}^{\prime}$ ye ayarlanmıştır. Taşıyıcı gaz olarak helyum kullanılmış ve akış hızı $0.64 \mathrm{ml} / \mathrm{dk}$ olacak şekilde ayarlanmıştır. Enjeksiyon split oranı 1:80 olarak ayarlanmıştır. GC-FID sisteminin kontrolü için LabSolution bilgisayar programı ve standart olarak FAME mix 37 standardı (Supelco) kullanılmıştır. FAME pikleri; alıkonma zamanları ve standartta belirtilen zincir uzunlukları kıyaslanarak teşhis edilmiştir.

Bu çalışmada verilen yağ asitlerinin uluslararası kısaltmaları aşağıda verilmiştir.

Miristik asit (myristic acid, C14:0), palmitik asit (palmitic acid, C16:0), stearik asit (stearic acid, C18:0), oleik asit (oleic acid, C18:1n9c), linoleik asit (linoleic acid, C18:2n6c), eikosenoik asit (cis-11eicosenoic acid, C20:1), linoleik asit (linolenic acid, C18:3n3), erusik asit (erucic acid C22:1n9), dokosadionik asit (cis-13,16-docosadienoic acid, C22:2). Doymuş yağ asitleri (DYA), Tekli Doymamış Yağ Asitleri (TDYA), Çoklu Doymamış Yağ Asitleri (ÇDYA), Toplam Doymamış Yağ Asitleri (T+ÇDYA), omega-3 (n-3), omega-6 (n-6), omega-9 (n-9).

Çalışmada Al ve TI indeksi Peiretti and Meineri, (2008) ve (Boz ve ark., 2019), besleyici değer ve istenilen yağ asitleri indeksi Caneque ve ark. (2005) ve (Boz ve ark., 2019), h/H indeksi Ahmed ve ark. (2015)'e göre hesaplanmıştır.

Al (aterojenik indeks $)=\left(\mathrm{C} 12: 0+\left(4^{*} \mathrm{C} 14: 0\right)+\right.$ C16:0)/ $\Sigma T+C ̧ D Y A$,

$\mathrm{TI}$ (trombojenik indeks $)=(\mathrm{C} 14: 0+\mathrm{C} 16: 0+$ C18:0)/[(0.5*TDYA $)+\left(0.5^{*} \sum n 6\right)+\left(3^{*} \sum n 3\right)+$ $\left.\left(\Sigma \mathrm{n} 3 / \sum \mathrm{n} 6\right)\right]$,

BDi (Besleyici değer indeksi $)=($ C18:0 + C18:1)/C16:0,

IYA (İstenilen Yağ Asitleri)= (C18:0 + T+ÇDYA),

$\mathrm{h} / \mathrm{H}$ (hipokolesterolemik / hiperkolesterolemik indeksi) $=$ [(toplam C18:1 cis-9, C18:2 n6, C20:4 n6, C18:3 n3, C20:3 n6, C20:5 n3, ve C22:6 n3)/(toplam C14:0 ve $\mathrm{C} 16: 0)]$.

Yağ asitlerinden (toplam 37) bütün örneklerde (göğüs ve but) tespit edilemeyenlere ve çok düşük oranda olanlara çizelgelerde yer verilmemiştir.
Toplam ve indeks değerlerin hesaplamasında ise tüm yağ asitleri değerleri kullanılmıştır.

Deneme tesadüf blokları deneme desenine göre düzenlenmiştir (2 yetiştirme sistemi, 3 kesim yaşı). Elde edilen verilerin değerlendirilmesinde yetiştirme sistemi ve kesim yaşı varyans analizi (bootstrap) ile değerlendirilmiştir. Kesim yaşında ortalamalar arasındaki farklılıkları belirlemek amacıyla Duncan çoklu karşılaştırma testi kullanılmıştır (Özdamar, 2002). Analizlerde SPSS 20.0 paket programı (Ondokuz Mayıs Üniversitesi lisansı ile) kullanılmıştır.

\section{Araştırma Bulguları ve Tartışma}

Çalışmada göğüs ve but eti besin madde kompozisyonu değerleri Çizelge 2'de verilmiştir. Göğüs etinde besin madde kompozisyonu üzerine yetiştirme sistemi, kesim yaşı ve yetiştirme sistemi $x$ kesim yaşı interaksiyonunun önemli bir etkisi olmamıştır $(P>0.05)$. But etinde de yetiştirme sisteminin besin madde kompozisyonu üzerine etkisi belirlenmemiştir ( $P>0.05)$. Bununla birlikte but eti kuru madde oranı üzerine kesim yaşı ve yetiştirme sistemi $x$ kesim yaşı interaksiyonun önemli düzeyde etkisi bulunmuş, 16. haftada daha düşük değerler tespit edilmiştir $(\mathrm{P}<0.05)$.

Bizim çalışmadan farklı olarak, Tejerina ve ark., (2009) serbest gezinmeli sistemde yetiştirilen beç tavuklarının göğüs eti yağ oranı ve but eti kuru madde oranının düşük, protein oranının ise yüksek olduğunu belirlemiştir. Mevcut çalışmaya benzer olarak ise göğüs etinde kül ve kuru madde oranının yetiştirme sistemine göre değişmediğini bildirmiştir. Laudadio ve ark., (2012) 12 haftalık yaştaki beç tavukları üzerine yaptığı çalışmada su miktarı, protein, yağ ve kül miktarını göğüs etinde sırasıyla \%26.95-26.75, \%23.54-23.61, \%1.85-2.17 ve \%1.24-1.29, but etinde de aynı sırayla \%24.6424.35, \%19.26-19.45, \%3.85-4.49 ve \%0.89-1.05 arasında tespit etmiştir.

Yaşla ile birlikte vücut ve kas kompozisyonunda değişiklikler meydana gelmekte, bunun sonucunda protein, yağ ve kuru madde oranlarında artışlar da dahil olmak üzere farklılıklar olabileceği bildirilmektedir (Aberle ve ark., 2001; Kokoszynski 
ve ark., 2011). Bu çalışmanın sonuçları sadece kuru madde oranı yönünden bu hipotez ile uyumludur. Çünkü bizim çalışmada yaşa bağlı olarak but etinde değişimler tespit edilmiştir. Musundire ve ark., (2017) beç tavuklarının göğüs eti ve karkas kompozisyonunda yaşın kuru madde ve protein oranı üzerine önemli etkisi olduğunu belirlemişlerdir.
Çalışmada yetiştirme sistemleri arasında besin madde kompozisyonu açısından farklılık görülmemesi, serbest gezinmeli üretim sistemi açısından bir avantaj oluşturabilir. Çünkü tüketiciler hayvan refahı ile ilgili kaygıları nedeniyle serbest gezinmeli üretim sistemlerinde yetiştirilen hayvansal ürünlere daha çok ilgi göstermekte ve tercih etmektedirler (Zaid ve ark., 2020).

Çizelge 2. Göğüs ve but etinde besin madde kompozisyonu (\%) Table 2. Chemical composition of breast and thigh muscle (\%)

\begin{tabular}{|c|c|c|c|c|c|c|c|c|c|}
\hline \multirow[b]{2}{*}{$\begin{array}{l}\text { Yetiştirme } \\
\text { sistemi } \\
\text { Production } \\
\text { systems }\end{array}$} & \multirow[b]{2}{*}{$\begin{array}{l}\text { Yaş } \\
\text { Age } \\
\text { (wk) }\end{array}$} & \multicolumn{4}{|c|}{ Breast meat } & \multicolumn{4}{|c|}{ Thigh meat } \\
\hline & & $\begin{array}{c}\text { Kuru } \\
\text { madde } \\
\text { Dry } \\
\text { matter }\end{array}$ & $\begin{array}{c}\text { Ham } \\
\text { Protein } \\
\text { Crude } \\
\text { protein }\end{array}$ & $\begin{array}{l}\text { Ham } \\
\text { Yağ } \\
\text { Crude } \\
\text { fat } \\
\end{array}$ & $\begin{array}{c}\text { Ham Kül } \\
\text { Crude } \\
\text { ash }\end{array}$ & $\begin{array}{c}\text { Kuru } \\
\text { madde } \\
\text { Dry } \\
\text { matter }\end{array}$ & $\begin{array}{c}\text { Ham } \\
\text { Protein } \\
\text { Crude } \\
\text { protein }\end{array}$ & $\begin{array}{l}\text { Ham } \\
\text { Yağ } \\
\text { Crude } \\
\text { fat }\end{array}$ & $\begin{array}{c}\text { Ham Kül } \\
\text { Crude } \\
\text { ash }\end{array}$ \\
\hline \multirow{3}{*}{$\begin{array}{l}\text { Kapalı } \\
\text { Intensive }\end{array}$} & 14 & 26.46 & 22.77 & 0.30 & 1.01 & 24.18 & 19.19 & 0.69 & 1.00 \\
\hline & 16 & 26.22 & 22.82 & 0.23 & 0.96 & 23.65 & 20.83 & 0.53 & 0.86 \\
\hline & 18 & 26.89 & 21.20 & 0.17 & 1.21 & 25.05 & 20.28 & 0.69 & 0.90 \\
\hline Serbest & 14 & 26.60 & 23.19 & 0.17 & 1.11 & 25.27 & 20.18 & 0.30 & 0.98 \\
\hline Gezinmeli & 16 & 26.44 & 23.39 & 0.29 & 0.88 & 24.31 & 19.66 & 0.66 & 0.86 \\
\hline Free range & 18 & 26.09 & 22.29 & 0.26 & 0.98 & 24.27 & 21.10 & 1.05 & 1.05 \\
\hline $\begin{array}{l}\text { OSH } \\
\text { SEM } \\
\end{array}$ & & 0.1266 & 0.3124 & 0.0354 & 0.0446 & 0.1778 & 0.2758 & 0.1022 & 0.0410 \\
\hline \multicolumn{10}{|c|}{$\begin{array}{c}\text { Ana Etkiler } \\
\text { Main effects }\end{array}$} \\
\hline \multicolumn{2}{|l|}{$\begin{array}{l}\text { Yetiştirme Sistemi } \\
\text { Production systems }\end{array}$} & NS & NS & NS & NS & NS & NS & NS & NS \\
\hline \multicolumn{2}{|l|}{$\begin{array}{l}\text { Kapalı } \\
\text { Intensive }\end{array}$} & 26.52 & 22.26 & 0.24 & 1.06 & 24.29 & 20.10 & 0.64 & 0.92 \\
\hline \multicolumn{2}{|l|}{$\begin{array}{l}\text { Serbest gezinmeli } \\
\text { Free range }\end{array}$} & 26.38 & 22.96 & 0.26 & 0.99 & 24.62 & 20.31 & 0.67 & 0.96 \\
\hline \multicolumn{2}{|l|}{$\begin{array}{l}\text { Yaş } \\
\text { Age (wk) }\end{array}$} & NS & NS & NS & NS & $*$ & NS & NS & NS \\
\hline \multicolumn{2}{|l|}{14} & 26.53 & 22.98 & 0.24 & 1.06 & $24.73^{\mathrm{a}}$ & 19.68 & 0.50 & 0.99 \\
\hline \multicolumn{2}{|l|}{16} & 26.33 & 23.11 & 0.26 & 0.92 & $23.98^{b}$ & 20.24 & 0.60 & 0.86 \\
\hline \multicolumn{2}{|l|}{18} & 26.49 & 21.75 & 0.24 & 1.10 & $24.66^{\mathrm{a}}$ & 20.69 & 0.87 & 0.97 \\
\hline \multicolumn{2}{|l|}{$\begin{array}{l}\text { YS } \times \text { Yaş } \\
P S \times \text { Age }\end{array}$} & NS & NS & NS & NS & $*$ & NS & NS & NS \\
\hline
\end{tabular}

YS: yetiştirme sistemi, OSH: ortalama standart hata, ${ }^{*}:$ P $<0.05$; NS: P>0.05, ${ }^{a, b}$ Aynı sütunda farklı üstel harflerle ifade edilen değerler istatistiksel olarak birbirinden farklıdır

PS: production systems, SEM: standard error of the mean, NS: $\mathrm{P}>0.05,{ }^{*} \mathrm{P}<0.05$. a,b Differences in superscript letters within columns represent significant differences among the groups

Birçok ülkede yağ ve yağ asitlerinin tüketiciler tarafından sağlıksız olduğu düşünülmektedir. Fakat yağ ve yağ asitleri hem yağ dokusunda hem de et dokusunda et kalitesine olumlu katkıda bulunmakta ve et besin değerinin önemli bir bileşeni olarak görev almaktadır (Wood ve ark., 2008). Ayrıca etin yağ ve yağ asitleri kompozisyonu, et kalitesi ve besleyici değer açısından önem arz etmektedir (Öz and Çelik, 2015). İnsanların ve özellikle bebek beslenmesinde yağ içeriğinin miktarı, enerji üretimi, yağda eriyen vitaminlerin emilimi ve esansiyel yağ asitlerinin temin edilmesi açısından gereklidir (Can et al., 2009).

Göğüs etinde palmitik asit (C16:0), stearik asit (C18:0) ve erusik asit (C22:1n9) serbest gezinmeli, oleik asit (C18:1n9c) ise kapalı yetiştirme sisteminde daha yüksek bulunmuştur $(P<0.05$; Çizelge 3). Yaşın göğüs eti yağ asitleri üzerine oleik asit (C18:1n9c) dışında önemli bir etkisi olmamıştır $(P>0.05)$. Oleik asit 18. haftada daha yüksek bulunmuştur $(P<0.05)$.

But etinde stearik asit (C18:0) kapalı, oleik asit (C18:1n9c) ise serbest gezinmeli yetiştirme 
sisteminde daha yüksek olarak belirlenmiştir $P<0.05)$. Diğer yağ asitleri üzerine yetiştirme sisteminin etkisi önemsiz bulunmuştur ( $P>0.05)$.

Kesim yaşı but eti eikosenoik asit (C20:1) ve erusik asit (C22:1n9) üzerine önemli düzeyde etkili olmuştur ( $P<0.05$; Çizelge 4). Eikosenoik asit
(C20:1) 14 ve 16. haftada, erusik asit (C22:1n9) ise 18. haftada daha yüksek bulunmuştur $(P<0.05)$. Göğüs etinde yetiştirme sistemi $x$ kesim yaşı interaksiyonu önemsiz iken ( $P>0.05)$, but etinde ise sadece eikosenoik asit (C20:1) değeri bakımından önemli bulunmuştur $(\mathrm{P}<0.05)$.

Çizelge 3. Göğüs etinde yağ asitleri kompozisyonu (\%)

Table 3. Fatty acid composition of breast muscle (\%)

\begin{tabular}{|c|c|c|c|c|c|c|c|c|c|c|}
\hline \multirow{2}{*}{$\begin{array}{l}\text { YS } \\
P S\end{array}$} & \multirow{2}{*}{$\begin{array}{c}\text { Yaş } \\
\text { Age (wk) }\end{array}$} & \multicolumn{9}{|c|}{$\begin{array}{l}\text { Yağ asitleri } \\
\text { Fatty acids }\end{array}$} \\
\hline & & C14:0 & C16:0 & C18:0 & C18:1n9c & $\mathrm{C} 18: 2 \mathrm{n} 6 \mathrm{c}$ & C20:1 & C18:3n3 & C22:1n9 & C22:2 \\
\hline \multirow{3}{*}{$\begin{array}{l}\mathrm{K} \\
\mathrm{l}\end{array}$} & 14 & 1.02 & 23.89 & 16.19 & 24.59 & 24.49 & 0.71 & 0.24 & 10.22 & 1.54 \\
\hline & 16 & 1.34 & 27.54 & 17.98 & 17.61 & 18.73 & 0.58 & 0.15 & 2.24 & 1.55 \\
\hline & 18 & 0.93 & 20.57 & 10.57 & 40.57 & 20.49 & 1.01 & 0.18 & 0.62 & 0.81 \\
\hline \multirow{3}{*}{$\begin{array}{l}\text { SG } \\
F R\end{array}$} & 14 & 1.01 & 30.99 & 26.05 & 10.81 & 11.64 & 0.50 & 0.18 & 2.06 & 1.04 \\
\hline & 16 & 0.91 & 31.09 & 23.26 & 17.20 & 16.13 & 0.47 & 0.19 & 2.55 & 0.86 \\
\hline & 18 & 1.01 & 30.18 & 19.87 & 21.14 & 18.04 & 0.57 & 0.30 & 2.28 & 0.91 \\
\hline \multicolumn{2}{|l|}{$\begin{array}{l}\text { OSH } \\
\text { SEM }\end{array}$} & 0.063 & 1.524 & 1.773 & 3.199 & 1.659 & 0.072 & 0.019 & 0.256 & 0.156 \\
\hline \multicolumn{11}{|c|}{$\begin{array}{c}\text { Ana etkiler } \\
\text { Main effects }\end{array}$} \\
\hline \multicolumn{2}{|l|}{$\begin{array}{l}\text { YS } \\
P S\end{array}$} & NS & $*$ & $*$ & $*$ & NS & NS & NS & $*$ & NS \\
\hline \multicolumn{2}{|l|}{$\begin{array}{l}\mathrm{K} \\
\mathrm{I}\end{array}$} & 1.10 & 24.00 & 14.91 & 27.59 & 21.24 & 0.77 & 0.19 & 1.36 & 1.30 \\
\hline \multicolumn{2}{|l|}{$\begin{array}{l}\text { SG } \\
F R\end{array}$} & 0.98 & 30.76 & 23.06 & 16.38 & 15.27 & 0.49 & 0.24 & 2.30 & 0.94 \\
\hline \multicolumn{2}{|c|}{$\begin{array}{l}\text { Yaş } \\
\text { Age (wk) }\end{array}$} & NS & NS & NS & $*$ & NS & NS & NS & NS & NS \\
\hline \multicolumn{2}{|c|}{14} & 1.02 & 27.44 & 21.12 & $17.70^{b}$ & 18.07 & 0.57 & 0.23 & 1.64 & 1.29 \\
\hline \multicolumn{2}{|l|}{16} & 1.12 & 29.32 & 20.62 & $17.40^{b}$ & 17.43 & 0.53 & 0.17 & 2.40 & 1.21 \\
\hline \multicolumn{2}{|l|}{18} & 0.97 & 25.38 & 15.22 & $30.86^{\mathrm{a}}$ & 19.27 & 0.79 & 0.24 & 1.45 & 0.86 \\
\hline \multicolumn{2}{|c|}{$\begin{array}{l}\text { YS X Yaş } \\
\text { PS } \times \text { Aqe }\end{array}$} & NS & NS & NS & NS & NS & NS & NS & NS & NS \\
\hline
\end{tabular}

YS: yetiştirme sistemi, Y: yaş, K: kapalı, SG: serbest gezinmeli, OSH: ortalama standart hata, ${ }^{*}: \mathrm{P}<0.05 ; \mathrm{NS}$ : P $>0.05$, a,bAynı sütunda farklı üstel harflerle ifade edilen değerler istatistiksel olarak birbirinden farklıdır

PS: production systems, I: intensive, FR: free range, SEM: standart error of mean, ${ }^{*}:$ P<0.05; NS: P>0.05, a,b Differences in superscript letters within columns represent significant differences among the groups

Göğüs etinde doymuş yağ asitleri (DYA) serbest gezinmeli sistemde, toplam doymamış yağ asitleri ( $T+$ ÇDYA) ve omega-9 ( $\mathrm{n}-9)$ ise kapalı üretim sisteminde daha yüksek bulunmuştur $(\mathrm{P}<0.05$; Çizelge 5). Kesim yaşının göğüs eti toplam yă̆ asitleri (T+ÇDYA) üzerine etkisi omega-9 (n-9) dışında önemsiz olduğu belirlenmiştir ( $P>0.05)$. Omega-9 (n-9) yaşa bağlı olarak 18. haftada daha yüksek belirlenmiştir $(P<0.05)$.

But etinde toplam tekli doymamış yağ asitleri (TDYA) ve omega-9 ( $n-9)$ serbest gezinmeli üretim sisteminde daha yüksek bulunmuştur $(P<0.05)$. Kesim yaşına bağlı olarak omega-3 (n-3) 18. haftada daha yüksek bulunmuştur $(P<0.05$; Çizelge 6). Göğüs ve but etinde yetiştirme sistemi $x$ kesim yaşı interaksiyonu önemsiz bulunmuştur $(P>0.05)$.

Bernacki ve ark., (2012) 14 hafta kapalı yetiştirme sisteminde üretilen beyaz ve gri beç tavuklarında göğüs eti doymuş yağ asitlerini \% 42.8-43.5, tekli doymamış yağ asitleri miktarını \% 20.0-20.3, çoklu doymamış yağ asitlerini \%36.237.2 , toplam doymamış yağ asitlerini ise \%56.557.2 arasında tespit etmiştir. Laudadio ve ark., (2012) 12 hafta kapalı sistemde yetiştirilen beç tavuklarında bizim çalışmaya göre göğüs ve but etinde daha yüksek C14:0, C18:1n9c, C18:2n6c, C18:3n3, TDYA, ÇDYA, n-3 ve $n-6$, daha düşük C16:0, C18:0 ve DYA tespit etmiştir. Aynı çalışmada göğüs etinde doymuş yağ asitleri, tekli doymamış yağ asitleri ve aşırı doymuş yağ asitleri sırasıyla 
\%24.98-26.78, \%38.58-40.30 ve \%32.92-36.44, but etinde ayn sırayla \%27.50-30.00, \%38.14-39.23 ve \%30.77-34.36 olarak belirlemiştir. Tlhong (2008), yaptığı çalışmada 15 haftalık yaştaki beç tavuklarında göğüs ve but etinde doymuş, tekli doymamış ve aşırı doymamış yağ asitlerini sırasıyla \%24.60-26.77, \%25.11-27.28 ve \%46.24-50.29 arasında belirlemiştir. Bizim çalışmamızda literatüre göre daha yüksek DYA, daha düşük doymamış yağ sitleri, n-3 ve n-6 değerleri belirlenmiştir. Yaşa bağlı olarak (özellikle bizim çalışmada 18. hafta değerleri) literatüre benzer değerler de belirlenmiştir.

Doymuş yağ asitlerinden özellikle stearic C18:0, myristic $\mathrm{C} 14: 0$ ve palmitic asit C16:0 hiperkolesterolemi özelliklerinden dolayı çok önemlidir ki koroner kalp hastalığı ile ilişkilidir. Doymuş yağ asitleri yerine tekli doymamış yağ asitleri değerinin yüksek olması LDL kolestrolü ve toplam/HDL kolestrolü oranını azaltmada etkilidir (FAO/WHO, 2009). Kardiyovasküler sistem ve immünolojik işlemleri düzenlediğinden dolayı $n-3$ ve $n-6$ insan beslenmesinde önemli bir rol oynamaktadır (Grashorn, 2007). Ayrıca omega yağ asitleri beyin gelişimi, bağışıklık sisteminin güçlenmesi, koroner kalp hastalıklarının önlenmesinde görev almaktadır. Eksikliklerinde çeşitli deri hastalıkları, astım, büyümede gerileme, şeker ve çeşitli kanser türlerinin (göğüs ve prostat gibi) ortaya çıkması söz konusudur (Lewis et al., 2000).

Çizelge 4. But etinde yağ asitleri kompozisyonu (\%)

Table 4. Fatty acid composition of thigh muscle (\%)

\begin{tabular}{|c|c|c|c|c|c|c|c|c|c|c|}
\hline \multirow{2}{*}{$\begin{array}{l}\text { YS } \\
P S\end{array}$} & \multirow{2}{*}{$\begin{array}{c}\text { Yaş } \\
\text { Age (wk) }\end{array}$} & \multicolumn{9}{|c|}{$\begin{array}{l}\text { Yağ asitleri } \\
\text { Fatty acids }\end{array}$} \\
\hline & & C14:0 & C16:0 & C18:0 & C18:1n9c & $\mathrm{C} 18: 2 \mathrm{n} 6 \mathrm{c}$ & C20:1 & C18:3n3 & C22:1n9 & C22:2 \\
\hline \multirow{3}{*}{$\begin{array}{l}\mathrm{K} \\
\mathrm{I}\end{array}$} & 14 & 0.78 & 24.98 & 17.92 & 18.37 & 26.62 & 0.66 & 0.25 & 4.87 & 0.65 \\
\hline & 16 & 0.90 & 24.87 & 17.88 & 18.99 & 27.19 & 0.73 & 0.28 & 3.86 & 0.79 \\
\hline & 18 & 0.81 & 24.93 & 18.17 & 18.05 & 25.13 & 0.59 & 0.26 & 5.45 & 0.67 \\
\hline \multirow{3}{*}{$\begin{array}{l}\text { SG } \\
F R\end{array}$} & 14 & 0.91 & 26.33 & 17.95 & 19.22 & 24.72 & 0.74 & 0.27 & 4.00 & 0.74 \\
\hline & 16 & 0.89 & 24.56 & 15.55 & 25.16 & 24.84 & 0.68 & 0.27 & 3.08 & 0.61 \\
\hline & 18 & 0.82 & 25.21 & 17.29 & 19.70 & 24.85 & 0.65 & 0.25 & 5.01 & 0.53 \\
\hline $\begin{array}{l}\text { OSH } \\
\text { SEM }\end{array}$ & & 0,033 & 0.541 & 0.316 & 0.843 & 0.800 & 0.017 & 0.009 & 0.297 & 0.048 \\
\hline \multicolumn{11}{|c|}{$\begin{array}{l}\text { Ana etkiler } \\
\text { Main effects }\end{array}$} \\
\hline $\begin{array}{l}\text { YS } \\
P S\end{array}$ & & NS & NS & $*$ & $*$ & NS & NS & NS & NS & NS \\
\hline $\begin{array}{l}\mathrm{K} \\
\mathrm{I}\end{array}$ & & 0.83 & 24.93 & 17.99 & 18.47 & 26.32 & 0.66 & 0.27 & 4.73 & 0.70 \\
\hline $\begin{array}{l}\text { SG } \\
F R\end{array}$ & & 0.88 & 25.37 & 16.93 & 21.36 & 24.80 & 0.69 & 0.26 & 4.03 & 0.63 \\
\hline $\begin{array}{l}\text { Yaş } \\
\text { Age (wk }\end{array}$ & & NS & NS & NS & NS & NS & $*$ & NS & $*$ & NS \\
\hline 14 & & 0.85 & 25.66 & 17.94 & 18.80 & 25.67 & $0.70^{a}$ & 0.26 & $4.44^{\mathrm{ab}}$ & 0.69 \\
\hline 16 & & 0.90 & 24.72 & 16.71 & 22.08 & 26.01 & $0.71^{a}$ & 0.28 & $3.47^{b}$ & 0.70 \\
\hline 18 & & 0.82 & 25.07 & 17.73 & 18.88 & 24.99 & $0.62^{b}$ & 0.26 & $5.23^{a}$ & 0.60 \\
\hline $\begin{array}{l}Y S \times \text { Yaş } \\
P S \times A g \epsilon\end{array}$ & & NS & NS & NS & NS & NS & $*$ & NS & NS & NS \\
\hline
\end{tabular}

YS: yetiştirme sistemi, Y: yaş, K: kapalı, SG: serbest gezinmeli, OSH: ortalama standart hata, ${ }^{*}$ : P<0.05; NS: P>0.05, a,bAynı sütunda farklı üstel harflerle ifade edilen değerler istatistiksel olarak birbirinden farklıdır

PS: production systems, I: intensive, FR: free range, SEM: standart error of mean, ${ }^{*}$ : P<0.05; NS: P>0.05, a,bDifferences in superscript letters within columns represent significant differences among the groups

Çalışmada serbest gezinmeli sistemde daha yüksek olan Miristik asit (C14:0), palmitik asit (C16:0), stearik asit (C18:0) miktarlarına bağlı olarak göğüs eti doymuş yağ asitleri oranı yüksek belirlenmiştir. Yüksek çoklu doymamış yağ asitleri içeren etler, koroner kalp hastalığı ve diğer kronik hastalıkların insidansını azaltabilen fonksiyonel bileşenler olarak düşünüldüğünden önemli ilgi görmektedir (Laudadio ve ark., 2012). Çalışmamızda kapalı üretim sisteminde daha 
yüksek ÇDYA ve n-9 tespit edilmiştir. Bu durum serbest gezinmeli sistemde yetiştirilen beç tavuklarının dış gezinti alanındaki çevre koşullarından kaynaklanmış olabilir. Çünkü kanatlılara dış ortamda sağlanan beslemeye dönük avantaj ve dezavantajlar ortaya çıkabilmektedir. Hayvanların açık alanda yetiştirilmesinde sıcaklık, foto periyot, ışık yoğunluğu gibi kontrol edilemeyen ve doğal olarak değişen faktörler etkili olmaktadır. Bu sistemde kontrol edilemeyen yemlere, otlara, böceklere ve solucanlara ulaşabilmektedirler (Fanatico ve ark., 2005). Ayrıca göğüs etinde ÇDYA yetiştirme sistemine bağlı farklılık gösterirken, but etinde farklılık belirlenmemiştir. Bu durumun, kaslar arasındaki kas lifi tipindeki farklılıklarından kaynaklandığı düşünülmektedir. Kas lifi tipindeki farklılıklar besin madde kompozisyonu ve yağ asidi bileşimindeki değişimlere yansımaktadır (Wood ve ark., 2003). Yaşa bağlı farklılıkların ise özellikle artan canlı ağırlıklar nedeniyle ortaya çıktığı düşünülmektedir. Yaşla ile birlikte vücut ve kas kompozisyonunda değişimler meydana gelebilmektedir (Aberle ve ark., 2001; Kokoszynski ve ark., 2011).

Çizelge 5. Göğüs etinde toplam yağ asitleri kompozisyonu (\%)

Table 5. Total fatty acid composition of breast muscle (\%)

\begin{tabular}{|c|c|c|c|c|c|c|c|c|}
\hline \multirow{3}{*}{$\begin{array}{l}\text { Yetiştirme Sistemi } \\
\text { Production System }\end{array}$} & \multirow{3}{*}{$\begin{array}{c}\text { Yaş } \\
\text { Age (wk) }\end{array}$} & \multicolumn{7}{|c|}{$\begin{array}{l}\text { Toplam yağ asitleri } \\
\text { Total fatty acids }\end{array}$} \\
\hline & & DYA & TDYA & ÇDYA & $T+C ̧ D Y A$ & $n-3$ & $n-6$ & $n-9$ \\
\hline & & SFA & MUFA & PUFA & TUFA & $n-3$ & $n-6$ & $n-9$ \\
\hline \multirow{3}{*}{$\begin{array}{l}\text { Kapalı } \\
\text { Intensive }\end{array}$} & 14 & 42.42 & 30.38 & 27.19 & 57.58 & 0.96 & 24.49 & 25.81 \\
\hline & 16 & 48.32 & 30.52 & 21.16 & 51.68 & 0.54 & 18.73 & 19.85 \\
\hline & 18 & 33.06 & 45.17 & 21.76 & 66.93 & 0.36 & 20.49 & 41.30 \\
\hline \multirow{3}{*}{$\begin{array}{l}\text { Serbest Gezinmeli } \\
\text { Free range }\end{array}$} & 14 & 59.50 & 27.18 & 13.31 & 40.49 & 0.44 & 11.64 & 12.87 \\
\hline & 16 & 56.59 & 25.43 & 17.97 & 43.40 & 0.68 & 16.13 & 19.75 \\
\hline & 18 & 52.61 & 27.33 & 20.06 & 47.39 & 0.82 & 18.04 & 23.42 \\
\hline $\begin{array}{l}\text { OSH } \\
\text { SEM }\end{array}$ & & 3.286 & 2.506 & 1.777 & 3.286 & 0.082 & 1.659 & 3.042 \\
\hline \multicolumn{9}{|c|}{$\begin{array}{l}\text { Ana etkiler } \\
\text { Main effects }\end{array}$} \\
\hline $\begin{array}{l}\text { Yetiştirme Sistemi } \\
\text { Production Systems }\end{array}$ & & $*$ & NS & NS & $*$ & NS & NS & $*$ \\
\hline $\begin{array}{l}\text { Kapalı } \\
\text { Intensive }\end{array}$ & & 41.27 & 35.36 & 23.37 & 58.73 & 0.62 & 21.24 & 28.99 \\
\hline $\begin{array}{l}\text { Serbest gezinmeli } \\
\text { Free range }\end{array}$ & & 56.24 & 26.65 & 17.11 & 43.76 & 0.65 & 15.27 & 18.68 \\
\hline $\begin{array}{l}\text { Yaş } \\
\text { Age (wk) }\end{array}$ & & NS & NS & NS & NS & NS & NS & $*$ \\
\hline 14 & & 50.96 & 28.78 & 20.25 & 49.04 & 0.70 & 18.07 & $19.34^{b}$ \\
\hline 16 & & 52.46 & 27.98 & 19.56 & 47.54 & 0.61 & 17.43 & $19.80^{b}$ \\
\hline 18 & & 42.84 & 36.25 & 20.91 & 57.16 & 0.59 & 19.27 & $32.36^{a}$ \\
\hline $\begin{array}{l}\text { YS } \times \text { Yaş } \\
\text { PS } \times \text { Age }\end{array}$ & & NS & NS & NS & NS & NS & NS & NS \\
\hline
\end{tabular}

YS: yetiştirme sistemi, OSH: ortalama standart hata, ${ }^{*}: \mathrm{P}<0.05$; NS: $\mathrm{P}>0.05,{ }^{a, b}$ Aynı sütunda farklı üstel harflerle ifade edilen değerler istatistiksel olarak birbirinden farklıdır

PS: production systems, SEM: standart error of mean, *: P<0.05; NS: P >0.05, a,b Differences in superscript letters within columns represent significant differences among the groups

SFA: saturated fatty acids, MUFA: monounsaturated, fatty acids, PUFA: poly-unsaturated, fatty acids, TUFA: total unsaturated fatty acids, n3: omega-3, n-6: omega 6, n-9: omega 9

Yağ asitlerinin dengeli olması etin duyusal özellikleri, uzun süreli depolanması ve pişirme sürecinde oksidasyon nedeniyle önemli bir konudur (Zhou ve ark., 2012). Doymamış yağ asitleri sağlık açısından olumlu olsa da, doymuş yağ asitlerine göre daha kolay otooksidasyona uğrar (Mottram, 1998). Yağ asitleri yüksek miktarda uzun zincirli PUFA içerdiğinde, oksidatif stabilite düşer ve sonuç olarak et lezzeti negatif yönde etkilenir (Lu et al., 2008). Bu nedenle et ve abdominal yağın besin değeri ve sağlık açısından değerlendirilmesi amacıyla indeks değerler (TDYA/DYA, ÇDYA/DYA, T+ÇDYA/DYA, Al, TI, BDi, h/H, iYA) yaygın olarak kullanılmaktadır. 
Çizelge 6. But etinde toplam yağ asitleri kompozisyonu (\%)

Table 6. Total fatty acid composition of thigh muscle (\%)

\begin{tabular}{|c|c|c|c|c|c|c|c|c|}
\hline \multirow{3}{*}{$\begin{array}{l}\text { Yetiştirme Sistemi } \\
\text { Production systems }\end{array}$} & \multirow{3}{*}{$\begin{array}{c}\text { Yaş } \\
\text { Age (wk) }\end{array}$} & \multicolumn{7}{|c|}{$\begin{array}{l}\text { Toplam yağ asitleri } \\
\text { Total fatty acids }\end{array}$} \\
\hline & & DYA & TDYA & ÇDYA & T+ÇDYA & $n-3$ & $n-6$ & $n-9$ \\
\hline & & SFA & MUFA & PUFA & TUFA & $n-3$ & $n-6$ & $n-9$ \\
\hline \multirow{3}{*}{$\begin{array}{l}\text { Kapalı } \\
\text { Intensive }\end{array}$} & 14 & 45.20 & 25.47 & 29.32 & 54.79 & 1.61 & 26.62 & 23.24 \\
\hline & 16 & 45.38 & 24.84 & 29.77 & 54.62 & 1.40 & 27.19 & 22.91 \\
\hline & 18 & 45.63 & 26.37 & 27.99 & 54.36 & 1.76 & 25.16 & 23.53 \\
\hline \multirow{3}{*}{$\begin{array}{l}\text { Serbest gezinmeli } \\
\text { Free range }\end{array}$} & 14 & 46.88 & 26.17 & 26.94 & 53.11 & 1.18 & 24.72 & 23.26 \\
\hline & 16 & 42.17 & 31.15 & 26.67 & 57.82 & 0.96 & 24.84 & 28.30 \\
\hline & 18 & 44.84 & 27.49 & 27.66 & 55.15 & 1.88 & 24.87 & 24.74 \\
\hline $\begin{array}{l}\text { OSH } \\
\text { SEM }\end{array}$ & & 0.621 & 0.746 & 0.882 & 0.621 & 0.115 & 0.802 & 0.636 \\
\hline \multicolumn{9}{|c|}{$\begin{array}{l}\text { Ana etkiler } \\
\text { Main effects }\end{array}$} \\
\hline $\begin{array}{l}\text { Yetiştirme Sistemi } \\
\text { Production systems }\end{array}$ & & NS & $*$ & NS & NS & NS & NS & $*$ \\
\hline $\begin{array}{l}\text { Kapalı } \\
\text { Intensive }\end{array}$ & & 45.41 & 25.56 & 29.03 & 54.59 & 1.59 & 26.32 & 23.23 \\
\hline $\begin{array}{l}\text { Serbest gezinmeli } \\
\text { Free range }\end{array}$ & & 44.63 & 28.27 & 27.09 & 55.36 & 1.34 & 24.81 & 25.43 \\
\hline $\begin{array}{l}\text { Yaş } \\
\text { Age (wk) }\end{array}$ & & NS & NS & NS & NS & $*$ & NS & NS \\
\hline 14 & & 46.04 & 25.82 & 28.13 & 53.95 & $1.40^{\mathrm{ab}}$ & 25.67 & 23.25 \\
\hline 16 & & 43.78 & 28.00 & 28.22 & 56.22 & $1.18^{b}$ & 26.01 & 25.60 \\
\hline 18 & & 45.24 & 26.93 & 27.83 & 54.76 & $1.82^{\mathrm{a}}$ & 25.02 & 24.13 \\
\hline $\begin{array}{l}\text { YS } \times \text { Yaş } \\
\text { PS } \times \text { Age }\end{array}$ & & NS & NS & NS & NS & NS & NS & NS \\
\hline
\end{tabular}

YS: yetiştirme sistemi, OSH: ortalama standart hata, ${ }^{*}: \mathrm{P}<0.05$; NS: P>0.05, ${ }^{a, b}$ Aynı sütunda farklı üstel harflerle ifade edilen değerler istatistiksel olarak birbirinden farklıdır

PS: production systems, SEM: standart error of mean, *: P<0.05; NS: P $>0.05$, a,b Differences in superscript letters within columns represent significant differences among the groups

SFA: saturated fatty acids, MUFA: monounsaturated, fatty acids, PUFA: poly-unsaturated, fatty acids, TUFA: total unsaturated fatty acids, $n$ 3: omega-3, n-6: omega 6, n-9: omega 9

Göğüs etinde TDYA/DYA, ÇDYA/DYA, BDi, h/H ve IYA oranı kapalı üretim sisteminde, Al ve TI serbest gezinmeli üretim sisteminde daha yüksek belirlenmiştir ( $P<0.05$; Çizelge 7$)$. Kesim yaşının yağ asitleri indeks değerleri üzerine etkisi ise önemsiz bulunmuştur ( $P>0.05)$.

But etinde TDYA/DYA oranı serbest gezinmeli yetiştirme siteminde ve 16 . haftada daha yüksek belirlenmiştir $(P<0.05)$. Diğer yağ asitleri indeks değerleri üzerine yetiştirme sistemi ve kesim yaşının etkisi önemsiz bulunmuştur $(P>0.05$; Çizelge 8). Yetiştirme sistemi $x$ kesim yaşı interaksyonu but eti TDYA/DYA oranı üzerine etkisi önemli, diğer özellikler üzerine hem göğüs hem de but etinde önemsiz belirlenmiştir ( $P>0.05)$.

Yağın besleyici değerini belirlemek için kullanılan ÇDYA/DYA oranının düşük olması $(<0.4)$ olumsuz olarak düşünülmektedir. Çünkü kolesterolemide bir artışa neden olabilmektedir (Santos-Silva et al., 2002). Çalışmamızda göğüs eti ÇDYA/DYA oranı serbest gezinmeli sistemde ve 14. haftada 0.4'ten düşük bulunmuştur. Bernacki ve ark. (2012), 14 hafta kapalı yetiştirme sisteminde üretilen beyaz ve gri beç tavuklarında toplam doymamış yağ asitleri/doymuş yağ asitleri oranını 1.30-1.34 arasında tespit etmiştir. 
Çizelge 7. Göğüs etinde yağ asitleri indeks değerleri

Table 7. Fatty acid indexes of breast muscle

\begin{tabular}{|c|c|c|c|c|c|c|c|c|}
\hline \multirow{3}{*}{$\begin{array}{l}\text { Yetiştirme sistemi } \\
\text { Production systems }\end{array}$} & \multirow{3}{*}{$\begin{array}{c}\text { Yaş } \\
\text { Age (wk) }\end{array}$} & \multicolumn{7}{|c|}{$\begin{array}{c}\text { Yağ asitleri indeks değerleri } \\
\text { Fatty acid indexes }\end{array}$} \\
\hline & & TDYA/DYA & ÇDYA/DYA & BDi & $\mathrm{Al}$ & $\mathrm{TI}$ & $h / H$ & IYA \\
\hline & & MUFA/SFA & PUFA/SFA & $N V$ & $A I$ & $T I$ & $h / H$ & $D F A$ \\
\hline \multirow{3}{*}{$\begin{array}{l}\text { Kapalı } \\
\text { Intensive }\end{array}$} & 14 & 0.80 & 0.74 & 1.82 & 0.53 & 1.48 & 2.24 & 73.77 \\
\hline & 16 & 0.66 & 0.45 & 1.29 & 0.66 & 1.85 & 1.29 & 69.66 \\
\hline & 18 & 1.43 & 0.65 & 2.57 & 0.37 & 0.96 & 2.93 & 77.50 \\
\hline \multirow{3}{*}{$\begin{array}{l}\text { Serbest gezinmeli } \\
\text { Free range }\end{array}$} & 14 & 0.46 & 0.22 & 1.19 & 0.87 & 2.80 & 0.71 & 66.54 \\
\hline & 16 & 0.45 & 0.32 & 1.30 & 0.81 & 2.43 & 1.05 & 66.67 \\
\hline & 18 & 0.53 & 0.39 & 1.38 & 0.74 & 2.07 & 1.31 & 67.26 \\
\hline \multicolumn{2}{|c|}{$\mathrm{OSH}$} & 0.128 & 0.074 & 0.178 & 0.064 & 0.219 & 0.278 & 1.598 \\
\hline \multicolumn{9}{|c|}{$\begin{array}{l}\text { Ana etkiler } \\
\text { Main effects }\end{array}$} \\
\hline \multicolumn{2}{|c|}{$\begin{array}{l}\text { Yetiştirme Sistemi } \\
\text { Production systems }\end{array}$} & $*$ & $*$ & $*$ & $*$ & $*$ & $*$ & $*$ \\
\hline \multicolumn{2}{|c|}{$\begin{array}{l}\text { Kapalı } \\
\text { Intensive }\end{array}$} & 0.97 & 0.62 & 1.89 & 0.52 & 1.43 & 2.15 & 73.65 \\
\hline \multicolumn{2}{|l|}{ Serbest gezinmeli } & 0.48 & 0.31 & 1.29 & 0.81 & 2.43 & 1.03 & 66.82 \\
\hline \multicolumn{2}{|l|}{ Age (wk) } & NS & NS & NS & NS & NS & NS & NS \\
\hline \multicolumn{2}{|l|}{14} & 0.63 & 0.48 & 1.50 & 0.70 & 2.14 & 1.47 & 70.16 \\
\hline \multicolumn{2}{|l|}{16} & 0.56 & 0.38 & 1.30 & 0.73 & 2.14 & 1.17 & 68.16 \\
\hline \multicolumn{2}{|l|}{18} & 0.98 & 0.52 & 1.97 & 0.56 & 1.51 & 2.12 & 72.38 \\
\hline \multicolumn{2}{|l|}{$\begin{array}{l}\text { YS } \times \text { Yaş } \\
\text { PS } \times \text { Age }\end{array}$} & NS & NS & NS & NS & NS & NS & NS \\
\hline
\end{tabular}

YS: yetiştirme sistemi, OSH: ortalama standart hata, ${ }^{*}: \mathrm{P}<0.05 ; \mathrm{NS}: \mathrm{P}>0.05$,

PS: production systems, SEM: standart error of mean, *: P<0.05; NS: P>0.05,

SFA: saturated fatty acids, MUFA: monounsaturated, fatty acids, PUFA: poly-unsaturated, fatty acids, NV: nutritive value, Al: atherogenic index, Tl: thrombogenic index $\mathrm{h} / \mathrm{H}$ :hypocholesterolaemic/hypercholesterolaemic ratio, DFA:desirable fatty acids

Besleyici değer indeksi ((C18:0+C18:1)/C16:0) yağ içeriğinin sağlıklı olduğunu gösterir ve yağ asitleri bütünü içerisinde önemli bir parçayı oluşturur. Palmitik asit (C16:0) kan kolesterol seviyesini artırma eğilimi gösterirken, stearik asit (C18:0) kan kolesterol düzeyini etkilemez ve oleik asit (C18:1) azalmasına yardımcı olur (Caneque et al., 2005). Çalışmamızda göğüs eti C16:0 yağ asidi yüksekliği nedeniyle bu değer serbest gezinmeli üretim sisteminde daha düşüktür.

Al ve $\mathrm{TI}$ değerlerinin 1'in altında olması olumlu olarak kabul edilmektedir (Yakan et al., 2012). Al değerinin yüksek çıkması insan sağlığı yönünden zararlı varsayılmaktadır (Ulbricht and Southgate, 1991). Tam tersi durum, doymamış yağ asitlerinin kardiovasküler hastalıklara karşı koruyucu etkisi nedeniyle önemlidir (Manso et al., 2009). Çalışmamızda göğüs ve but eti Al değerleri olumlu olarak kabul edilen sınırlarda iken, TI değerleri bu sınırların üzerindedir. Çalışmada elde edilen doymuş yağ asitleri (DYA) değerlerinin yüksek olması bu duruma neden olmuştur.

Yağ asitlerinin foksiyonel etkilerine bağlı kullanılan $\mathrm{h} / \mathrm{H}$ değeri beslenme değerlendirmesi yönünden iyi bir yaklaşımdır (Ahmet et al., 2015). Kapalı sistemde yetiştirilen beç tavuklarının göğüs etinde daha iyi $\mathrm{h} / \mathrm{H}$ indeksi tespit edilmiştir.

İstenilen yağ asitleri (IYA) açısından doymamış yağ asitleri miktarının etkisiyle kapalı yetiştirme sisteminde üretilen beç tavuklarının göğüs etinde daha iyi değerler tespit edilmiştir.

Laudadio ve ark., (2012) 12 haftalık yaştaki beç tavuklarında bu çalışmaya göre göğüs ve but etinde daha yüksek $\mathrm{Al}$ ve $\mathrm{h} / \mathrm{H}$, daha düşük $\mathrm{Tl}$ tespit etmiştir. 
Çizelge 8. But etinde yağ asitleri indeks değerleri Table 8. Fatty acid indexes of thigh muscle

\begin{tabular}{|c|c|c|c|c|c|c|c|c|}
\hline \multirow{3}{*}{$\begin{array}{l}\text { Yetiştirme sistemi } \\
\text { Production systems }\end{array}$} & \multirow{3}{*}{$\begin{array}{c}\text { Yaş } \\
\text { Age (wk) }\end{array}$} & \multicolumn{7}{|c|}{$\begin{array}{c}\text { Yağ asitleri indeks değerleri } \\
\text { Fatty acid indexes }\end{array}$} \\
\hline & & TDYA/DYA & ÇDYA/DYA & BDi & $\mathrm{Al}$ & $\mathrm{TI}$ & $h / H$ & IYA \\
\hline & & MUFA/SFA & PUFA/SFA & $N V$ & $A I$ & $\mathrm{TI}$ & $h / H$ & $D F A$ \\
\hline \multirow{3}{*}{$\begin{array}{l}\text { Kapalı } \\
\text { Intensive }\end{array}$} & 14 & 0.56 & 0.65 & 1.46 & 0.51 & 1.41 & 1.78 & 72.72 \\
\hline & 16 & 0.55 & 0.66 & 1.48 & 0.52 & 1.44 & 1.82 & 72.50 \\
\hline & 18 & 0.58 & 0.62 & 1.46 & 0.52 & 1.42 & 1.72 & 72.53 \\
\hline \multirow{3}{*}{$\begin{array}{l}\text { Serbest gezinmeli } \\
\text { Free range }\end{array}$} & 14 & 0.56 & 0.57 & 1.41 & 0.57 & 1.56 & 1.64 & 71.06 \\
\hline & 16 & 0.74 & 0.64 & 1.67 & 0.49 & 1.33 & 2.02 & 73.37 \\
\hline & 18 & 0.61 & 0.62 & 1.48 & 0.52 & 1.36 & 1.77 & 72.45 \\
\hline \multicolumn{2}{|l|}{$\begin{array}{l}\text { OSH } \\
\text { SEM }\end{array}$} & 0.020 & 0.026 & 0.034 & 0.017 & 0.037 & 0.065 & 0.588 \\
\hline \multicolumn{9}{|c|}{$\begin{array}{c}\text { Effects } \\
\text { Main effects }\end{array}$} \\
\hline \multicolumn{2}{|c|}{$\begin{array}{l}\text { Yetiştirme sistemi } \\
\text { Production Systems }\end{array}$} & $*$ & NS & NS & NS & NS & NS & NS \\
\hline \multicolumn{2}{|c|}{$\begin{array}{c}\text { Kapalı } \\
\text { Intensive }\end{array}$} & 0.56 & 0.64 & 1.47 & 0.52 & 1.42 & 1.77 & 72.58 \\
\hline \multicolumn{2}{|c|}{$\begin{array}{l}\text { Serbest gezinmeli } \\
\text { Free range }\end{array}$} & 0.63 & 0.61 & 1.52 & 0.53 & 1.42 & 1.81 & 72.30 \\
\hline \multicolumn{2}{|c|}{$\begin{array}{c}\text { Yaş } \\
\text { Age (wk) }\end{array}$} & $*$ & NS & NS & NS & NS & NS & NS \\
\hline \multicolumn{2}{|c|}{14} & $0.56^{b}$ & 0.61 & 1.43 & 0.54 & 1.48 & 1.71 & 71.89 \\
\hline \multicolumn{2}{|l|}{16} & $0.64^{a}$ & 0.65 & 1.58 & 0.51 & 1.39 & 1.92 & 72.94 \\
\hline \multicolumn{2}{|l|}{18} & $0.59^{b}$ & 0.62 & 1.47 & 0.52 & 1.39 & 1.75 & 72.49 \\
\hline \multicolumn{2}{|l|}{$\begin{array}{l}\text { YS } \times \text { Yaş } \\
P S \times \text { Age }\end{array}$} & $*$ & NS & NS & NS & NS & NS & NS \\
\hline
\end{tabular}

YS: yetiştirme sistemi, OSH: ortalama standart hata, ${ }^{*}: \mathrm{P}<0.05 ; \mathrm{NS}: \mathrm{P}>0.05,{ }^{a, b} \mathrm{Ayn}$ sütunda farklı üstel harflerle ifade edilen değerler istatistiksel olarak birbirinden farklıdır

PS: production systems, SEM: standart error of mean, *: P<0.05; NS: P>0.05, a,bDifferences in superscript letters within columns represent significant differences among the groups

SFA: saturated fatty acids, MUFA: monounsaturated, fatty acids, PUFA: poly-unsaturated, fatty acids, NV: nutritive value, Al: atherogenic index, TI: thrombogenic index $\mathrm{h} / \mathrm{H}$ :hypocholesterolaemic/hypercholesterolaemic ratio, DFA:desirable fatty acids

Genel olarak, çalışmada elde edilen değerlerin diğer çalışmalar ile farklılık göstermesinin yetiştirme sistemi, besleme, yaş ve genotipe bağlı olduğu düşünülmektedir. Özellikle hayvanların tükettiği yemlerdeki ve sudaki yağ asitleri profili, etteki kas içi yağ asitlerini etkilemiş olabilir. Besleme rejimi ve su kaynaklarının kullanımına bağlı olarak yağ asitleri miktarı ve indeks değerlerinin değişebileceği bildirilmektedir (Öz ve Çelik, 2015). Ayrıca yetiştirme sistemi ve koşullarına bağı olarak hareket imkanı, yerleşim sıklığı ve gezinti alanı vejetasyonu farklılıkları da üretim ve et kalitesini değiştirebilmektedir (Cavani ve ark., 2009).

\section{Sonuçlar}

Sonuç olarak, bu çalışma ile beç tavuğu göğüs ve but etinde yaş ve yetiştirme sisteminin etkileri ortaya koyulmuştur. Tüketiciler tarafından daha fazla tercih edilen serbest gezinmeli sistemde doymuş yağ asitleri miktarı yüksek bulunmuştur. Yapılan tartışma ve literatür bilgilerine göre, çalışma sonuçları yetiştirme sistemi ve daha az özellikte de olsa yaşa bağlı olarak yağ asitleri ve indeks değerlerinde değişimler olabileceğini göstermektedir. Kesim yaşı ve yetiştirme sisteminin beç tavuğu etinin kimyasal kompozisyonu üzerine etkilerinin önemli farklılıklara neden olmadığı ve sadece bazı yağ asitlerinin düşük veya yüksek olmasının yetiştirme sisteminde bir tercihe neden olamayacağı düşünülmektedir. Yine de bu bilgiler ışığında insanlara sağlıklı ve dengeli diyetler sağlayan fonksiyonel gıda üretiminin zenginleştirebileceği öngörülmektedir.

\section{Ekler}

Bu çalışma Yozgat Bozok Üniversitesi tarafından desteklenmiştir (Proje no: 6602b-ZF/16-46). 
Çalışmada yer alan verilerin bir kısmı "International Poultry Science Congress of WPSA Turkish Branch'2018" adlı kongrede poster olarak sunulmuştur.

\section{Çıkar Çatışması Beyanı: Makale yazarları} aralarında herhangi bir çıkar çatışması olmadığını beyan ederler.

Yazar katkısı: Yazarlar çalışmaya eşit oranda katkı sunmuştur.

Etik Beyan: Çalışmadaki tüm işlemler Ondokuz Mayıs Üniversitesi Deney Hayvanları Etik Kurulu tarafından onaylanmıştır (Ondokuz Mayıs Üniversitesi Deney Hayvanları Etik Kurulu - Tarih: 31.03.2015 - Karar sayısı: 2015/16-24, Karar No: 2015-18).

\section{Kaynaklar}

Aberle, E. D., Forrest, J. C., Gerrard, D. E., \& Mills, E. W. (2001). Principles of meat science. 4th edn. (Dubuque, IA, Kendall/Hunt Publishing Co.).

Ahmet, S. T., Islam, M. M., Bostami, A. B. M. R., Mun, H. S., Kim, Y. J., \& Yang, C. J. (2015). Meat composition, fatty acid profile and oxidative stability of meat from broilers supplemented with pomegranate (Punica granatum L.) by-products. Food Chemistry, 188, 481488.

Anonymous (2021). Tarım ürünleri piyasa raporu, Kaz ve beç tavuğu eti, Ocak-2021. Retrieved from; Tarım ve Orman Bakanlığı, https://arastirma.tarimorman.gov.tr.

Baeza, E., Juin, H., Rebours, G., Constantin, P., Marche, G., \& Leterrier, C. (2001). Effect of genotype, sex and rearing temperature on carcase and meat quality of guinea fowl. British Poultry Science, 42(4), 470-476. DOI: 10.1080/00071660120070640.

Bernacki, Z., Bawej, M., \& Kokoszynski, D. (2012). Quality of meat from two guinea fowl (Numida meleagris) varieties. Archiv für Geflügelkunde, 76(3), 203-207.

Boz, M. A., Oz, F., Yamak, U. S., Sarıca, M., \& Cilavdaroglu, E. (2019). The carcass traits, carcass nutrient composition, amino acid, fatty acid, and cholesterol contents of local Turkish goose varieties reared in an extensive production system. Poultry Science, 98, 3067-3080.

DOI:http://dx.doi.org/10.3382/ps/pez125

Can, E., Cömert, S., Uslu, S., Bülbül, A., Bolat, F., \& Nuhoglu, A. (2009). The role of long chain polyunsaturated fatty acids on newborn nutrition. The Journal of Kartal Training Research Hospital, 20, 108-112.

Caneque, V., Diaz, M. T., Alvarez, I., Lauzurica, S., Perez, C., \& De la Fuente, J. (2005). The influences of carcass weight and depot on the fatty acid composition of fats of suckling Manchego lambs. Meat Science, 70, 373379.

Castellini, C., Mugnai, C., \& Dal Bosco, A. (2002). Effect of organic production system on broiler carcass and meat quality. Meat Science, 60, 219-225.

Cavani, C., Petracci, M., Trocino, A., \& Xiccato, G. (2009). Advances in research on poultry and rabbit meat quality. Italian Journal of Animal Science, 8, 741-750.

Embury, I. (2001). Raising guinea fowl. Agfact A5.0.8. New South Wales Agriculture Publications, New South Wales, Australia.

Fanatico, A. C., Pillai, P. B., Cavitt, L. C., Owens, C. M. \& Emmert, J. L. (2005). Evaluation of slower-growing broiler genotypes grown with and without outdoor access: growth performance and carcass yield. Poultry Science, 84, 1321-1327. DOI:10.1093/ps/84.8.1321

FAO/WHO. (2009). Fats and fatty acids in human nutrition. Proceedings of the joint FAO/WHO expert consultation. November 10-14, 2008. Geneva, Switzerland. Annals of Nutrition Metabolism, 55, 5300.

Gökalp, H. Y., Kaya, M., Tülek, Y., \& Zorba, Ö. (2010). Et ve ürünlerinde kalite kontrolü ve laboratuvar uygulama kılavuzu. (V. Baskı), Atatürk Üniv. Yayınları, Yayın No: 751, Ziraat Fak. Yayın No: 318, Ders Kitapları Seri No:69, Atatürk Üniversitesi, Ofset Tesisi, Erzurum.

Grashorn, M. A. (2007). Functionality of poultry meat. Journal of Applied Poultry Research, 16, 99-106.

Kokoszynski, D., Bernacki, Z., Korytkowska, H., Wilkanowska, A., \& Piotrowska, K. (2011). Effect of age and sex on slaughter value of guinea fowl (Numida Meleagris). Journal of Central European Agriculture, 12(2), 255266. DOI: 10.5513/JCEA01/12.2.907.

Laudadio, V., Nahashon, S. N., \& Tufarelli, V. (2012). Growth performance and carcass characteristics of guinea fowl broilers fed micronized-dehulled pea (Pisum sativum L.) as a substitute for soybean meal. Poultry Science, 91, 2988-2996. DOI: http://dx.doi.org/ 10.3382/ps.2012-02473

Lewis, N. M., Seburg, S., \& Flanagan, N. L. (2000). Enriched eggs as a source of $\mathrm{N}-3$ polyunsaturated fatty acids for humans. Poultry Science, 79, 971-974.

Lu, P., Zhang, L. Y., Yin, J. D., Everts, A. K. \& Li, D. R. (2008). Effects of soybean oil and linseed oil on fatty acid compositions of muscle lipids and cooked pork flavour. Meat Science, 80, 910-918.

Magdelaine, P., Spiess, M., \& Valceschini, E. (2008). Poultry meat consumption trends in Europe. World's Poultry Science Journal, 64, 53-64.

Madzimure, J., \& Saina, H. (2011). Market potential for guinea fowl (Numidia meleagris) products. Tropical Health and Animal Production, 43, 1509-1515. DOI 10.1007/s11250-011-9835-z.

Manso, T., Bodas, R., Castro, T., Jimeno, V., \& Mantecon, A. R. (2009). Animal performance and fatty acid composition of lambs fed with different vegetable oils. Meat Science, 83, 511-516.

Mottram, D. S. (1998). Flavour formation in meat and meat products: a review. Food Chemistry, 62, 415-424.

Musundire, M. T., Halimani, T. E., \& Chimonyo, M. (2017). Physical and chemical properties of meat from scavenging chickens and helmeted guinea fowls in 
response to age and sex. British Poultry Science, 58(4), 390-396. DOI: 10.1080/00071668.2017.1313961

Nahashon, S. N., Adefope, N., Amenyenu, A., \& Wright, D. (2005). Effects of dietary metabolizable energy and crude protein concentrations on growth performance and carcass characteristics of French guinea broilers. Poultry Science, 84, 337-344.

Nahashon, S. N., Adefope, N., Amenyenu, A., Tyus, J., \& Wright, D. (2009). The effect of floor density on growth performance and carcass characteristics of French guinea broilers. Poultry Science, 88, 24612467. DOI: $10.3382 / p s .2008-00514$.

Okruszek, A., 2012. Fatty acid composition of muscle and adipose tissue of indigenous Polish geese breeds. Archiv Tierzucht, 55(3), 294-302.

Okruszek, A., Wołoszyn, J., Haraf, G., Orkusz, A., \& Wereńska, M. (2013). Chemical composition and amino acid profiles of goose muscles from native Polish breeds. Poultry Science, 92, 1127-1133.

Öz, F., \& Çelik, T., (2015). Proximate composition, color and nutritional profile of raw and cooked goose meat with different methods. Journal of Food Processing and Preservation, 39, 2442-2454.

Özdamar, K. (2002). Paket programlar ile istatistiksel veri analizi I., 4. baskı, Kaan Kitabevi, Eskişehir.

Peiretti, P. G., \& Meineri, G. (2008). Effects on growth performance, carcass characteristics, and the fat and meat fatty acid profile of rabbits fed diets with chia (Salvia hispanica L.) seed supplements. Meat Science, 80, 1116-1121.

Santos-Silva, J., Bessa, R. J. B., \& Santos-Silva, F. (2002). Effect of genotype, feeding system and slaughter weight on the quality of light lambs. Livestock Production Science, 77, 187-194.

Sarıca, M., Camcı, Ö., \& Selçuk, E. (2003). Bıldırcın, sülün, keklik, etçi güvercin, beç tavuğu ve devekuşu yetiştiriciliği. Ondokuz Mayıs Üniversitesi, Ziraat Fakültesi Baskı Ünitesi, Ders Kitabı No, 4. Genişletilmiş III. Baskı, Samsun.

Sarıca, M., Boz, M. A., Yamak, U. S., \& Ucar, A. (2019). Effect of production system and slaughter age on some production traits of guinea fowl: Meat quality and digestive traits. South African Journal of Animal Science, 49(1), 192-199.

DOI: http://dx.doi.org/10.4314/sajas.v49i1.22.

Satchithanandam, S., Fritsche, J., \& Rader J. I. (2001). Extension of AOAC Official Method 996.01 to the Analysis of Standard Reference Material (SRM) 1846 and Infant Formulas. Journal of AOAC International, 84, 805-813.

Tejerina, D., Lopez-Parra, M.M., \& Garcia-Torres, S. (2009). Potential used of near infrared reflectance spectroscopy to predict meat physico-chemical composition of guinea fowl (Numida meleagris) reared under different production systems. Food Chemistry, 113, 1290-1296.

Tlhong, T. M. (2008). Meat quality of raw and processed Guinea Fowl (Numeda meleagris). The master's thesis degree in consumer science at Stellenbosch University.

Tufarelli, V., Dario, M., \& Laudadio, V. (2007). Effect of xylanase supplementation and particle-size on performance of guinea fowl broilers fed wheat-based diets. International Journal of Poultry Science, 4, 302307.

Ulbricht, T. L., \& Southgate, D. A. (1991). Coronary heart disease: seven dietary factors. The Lancet, North Am. Ed. 338, 985-992.

Wood, J. D., Richardson, R. I., Nute, G. R., Fisher, A. V., Campo, M. M., Kasapidou, E., Sheard, P. R., \& Enser, M. (2003). Effects of fatty acids on meat quality: a review. Meat Science, 66, 21-32.

Wood, J. D., Enser, M., Fisher, A. V., Nute, G. R., Sheard, P. R., Richardson, R. I., Hughes, S. I., \& Whittington, F. M. (2008). Fat deposition, fatty acid composition and meat quality: A review. Meat Science, 78, 343-358.

Yakan, A., Aksu Elmali, D., Elmali, M., Sahin, T., Motor, S., \& Can, Y. (2012). Carcass and meat quality characteristics of White and multicolor geese under local breeder conditions. Kafkas Üniversitesi Veteriner Fakültesi Dergisi, 18, 663-670.

Yakar, Y., \& Tekeli, Y. (2019). Effect of feeding with safflower (Carthamus tinctorius L.) seed added mixed feed on the amount of fatty acids composition and cholesterol in chicken meat. Harran Tarım ve Gıda Bilimleri Dergisi. 23(1), 69-77. DOI: https://doi.org/10.29050/harranziraat.449027.

Yamak, U. S., Sarica, M., Boz, M. A., \& Ucar, A. (2018). Effect of production system (barn and free range) and slaughter age on some production traits of guinea fowl. Poultry Science, 97, 47-53. DOI: http://dx.doi.org/10.3382/ps/pex265

Yıldırım, A., (2009). Etlik beç tavuklarının beslenmesi. Hayvansal Üretim, 50(2), 60-65.

Zaid, M., Hussain, J., Mahmud, A., Javed, K., Shaheen, M.S., Usman, M., Ghayas, A., \& Ahmad, S. (2020). Carcass traits, meat quality, and sensory attributes of fastgrowing broilers given outdoor access at different ages. Turkish Journal of Veterinary and Animal Science, 44, 1039-1046. DOI:10.3906/vet-2003-92

Zhou, L. J., Wu, H., Li, J. T., Wang, Z. Y., \& Zhang, L. Y. (2012). Determination of fatty acids in broiler breast meat by near-infrared reflectance spectroscopy. Meat Science, 90, 658-664. 